See discussions, stats, and author profiles for this publication at: https://www.researchgate.net/publication/265339523

\title{
Exploring the Role of Discourse in Marketing and Consumer Research
}

Article in Journal of Consumer Behaviour · January 2015

DOI: $10.1002 / \mathrm{cb} .1497$

CITATIONS

9

2 authors:

Robert Caruana

University of Nottingham

20 PUBLICATIONS 430 CITATIONS

SEE PROFILE

Some of the authors of this publication are also working on these related projects:

Responsible Tourism View project

Special Issue on "Modern slavery in business" in Business \& Society View project
James Fitchett

University of Leicester

44 PUBLICATIONS 633 CITATIONS

SEE PROFILE 
Exploring the Role of Discourse in Marketing and Consumer Research

James Fitchett, University of Leicester (j.fitchett@le.ac.uk)

Rob Caruana, University of Nottingham, (robert.caruana@nottingham.ac.uk) 


\title{
Exploring the Role of Discourse in Marketing and Consumer Research
}

\begin{abstract}
:
This paper reviews the development of discourse based analysis in marketing and consumer research and outlines the application of various forms of discourse analysis (DA) as an approach. The paper locates this development alongside broader disciplinary movements and restates the potential for Critical Discourse Analysis (CDA) in marketing and consumer behaviour research. We argue that discourse based approaches have considerable potential and application particularly in terms of supporting disciplinary reflexivity and research criticality. A discursive lens offers novel ways of understanding marketing as a subject/discipline as well as how marketing academics conceive and investigate objects of marketing inquiry. The paper outlines some of the ways that discourse analysis, and especially Critical Discourse Analysis, could be developed and applied in marketing and consumer research. We provide a critical review of the development of discourse and text based studies in marketing and consumer research, and show how this has shaped, framed and limited the application and utilization of discourse analysis in particular ways. We then outline the main principles and features of discourse analysis and highlight how these approaches could be applied to a range of marketing and consumer behaviour issues and contexts. The paper offers an up to date critical reflection on the development of discourse based approaches, promoting reflexivity whilst providing empirical pathways to mainstream and critical research.
\end{abstract}




\section{Introduction}

Marketing and consumption depend largely on discourse for the creation, ordering, dissemination and reinforcement of product knowledge. The ability for marketers to infuse products with culturally powerful knowledge and meaning is enabled through shared discourse. While many consumer phenomena are often experienced as an individual (identity, the self, rational choice) they are (re)constructed in discourse. This has been most clearly demonstrated through the analysis of sexuality and gender. Although we typically experience our sexuality as 'our own' and a condition of our individuality, many discourse analysts have put forward detailed and compelling arguments which show that many aspects of 'our' gender are maintained and (re) constructed in shared social discourse (see for example, Sheon and Crosby 2004, Benwell 2005). Similarly, the capacity for consumers to interpret product meanings, to integrate them into their brand experiences (Roper et al., 2013) and articulate identity and 'positionality' to others (Dobscha and Ozanne, 2001) is in part facilitated by discourse. Whilst consumers draw down on shared social discourses on the body (Borgerson, and Schroeder, 2002), around gender, 'naturalness', youth and beauty (See. Thompson's, 2004 discussion of Health Marketing Discourses) they are equally available in interpretations of spaces that the consumer may inhabit; pristine, authentic, exotic, hedonic and liberatory (Caruana and Crane 2011 discussion of Tourism Marketing Discourses). If knowledge of marketing, and the relationship between markets consumers and products, is discursively ordered in this way, then discourse analysis presents itself as a significant lens for the further development of marketing and consumer research.

Whilse discourse analysis has much potential value, epistemological roadblocks have hindered its wider application in marketing and consumer research. This does not mean discourse analysis is non-existent but that it remains a relatively underrepresented approach in spite of the potential for interpreting marketing and consumer phenomena. This 
underrepresentation is manifest in part through resistance to the ontological view that marketing is socially constructed (Berger and Luckmann, 1971; Hackley, 2001) and in part in scepticism over language as a viable unit of analysis (Boje et al., 2004). Recently Skalen, a leading proponent of discourse studies in marketing notes, "Marketing research is little influenced by discourse analysis" (Skalen, 2010: 113). Skalen's (2010) reminds both marketing scholars and practitioners that their activities and practices are predicated upon (constructed through) a particular set of discursive conventions and ideology that are routinely overlooked (Marion, 2006, Fougere and Skalen 2013). The fact that discourse based approaches and analyses have been more readily and widely adopted in some fields more than others might suggest that the history, context and established epistemological norms of particular disciplines has an important influence on the degree of disciplinary receptiveness to discourse analysis. In its modern reconfiguration marketing and consumer research theory has, we would argue, been less compatible with discourse based readings because of the ontological status of the consumer as a sovereign, autonomous and individuated agency who has freedom to act in accordance with his or her own interests in the market. The idea that consumer autonomy is in some way constructed 'for' the consumer has been resisted more in marketing and consumer research than in other areas because it has the potential to question some fundamental, axiomatic assumptions in the discipline. An additional impediment to the uptake of discourse analysis, though not unique to marketing, is the commonly held belief in very limited views of language itself:

"Language is not only content; it is also context and a way to recontextualize content. We do not just report and describe with language; we also create with it. And what we create in language "uses us" in that it provides a point of view (a context) within which we "know" reality and orient our actions." Boje et al. (2004: 571) 
In marketing and consumer research, language is commonly viewed as a passive conduit of information, carrying signals (Roper et al., 2013) between highly autonomous, selfdetermining agents. This prevailing view is, understandably, rather unsettled by a discoursebased approach in which language itself becomes the active medium through which agents are constructed, and around which they are orientated towards certain kinds of practices and behaviours.

In an era where the role of markets and the activities of marketers are subject to intense public discussion and debate, the types of issues that lend themselves especially well to discourse analysis are all the more relevant (Ellis et al., 2011). In encouraging ethical reflection in marketing communications, for example, Borgerson and Schroeder (2002), show how visual representations of humans can disempower important social groupings, including consumers themselves. They highlight that historically marketers have re-presented cultural stereotypes in their product communications, reinforcing sometimes oppressive categorisations of peoples and relations:

"Typified representations, especially those that are racist or sexist, for example, undermine a group's dignity and historical integrity and cast a demeaning light upon their physical and intellectual habits" (Borgerson and Schroeder (2002: 578)

Thus, discourse based approaches can provide a methodological context for ethical reflection on the broader unintended consequences of marketing strategy beyond, for instance, the direct transfer of product meaning (McCraken, 1988).

In addition to revealing ethical issues in marketing, discourse based approaches highlight how the capacity for ethical reflection and ethical autonomy of consumers can be unintentionally limited by marketing. Caruana and Crane (2008) highlight how ostensibly responsible marketing discourse can inhibit consumers' capacity for ethical deliberation, 
identifying that "the institutionalized nature of consumer responsibility may potentially dissolve rather than provoke a broad moral imagination (2008: 1515)". These examples highlight the role of discourse analysis in better understanding the conditions of consumer (dis)empowerment (Shankar et al., 2006). Though rather than wielding the 'critical stick' at marketing, the real value of such discourse-based approaches is that they provide a methodological tool with which to firmly anchor critical research questions about the nature and implications of marketing realities, so that they may be positively transformed (Fairclough, 1992, 1995).

The pioneering research on discourse and textual analysis became foundational to a more general cultural turn in consumer research throughout the 2000s. This turn has become an established sub-discipline within marketing, focussing on approaches inspired broadly by ethnography and anthropology/material culture studies (Arnould and Thompson 2005). But text based approaches did not only morph into a form of cultural research, they also found application in an altogether different initiative which has come to be labelled as Critical Marketing (see Brownlie et al 1999, Saren et al 2007, Tadajewski and Brownlie 2008, MacLaren et al 2009). While it is true that Critical Marketing remains a relatively embryonic field, it nevertheless has the potential to make a significant contribution to the development of not only a discourse based approach, but a critical discourse analytical approach in marketing. In a similar fashion to Thompson's use of the term, Critical Marketing theorists have tended to identify marketing discourse as the broad context in which theory, knowledge and practice take place. The main point of departure here is that marketing is generally acknowledged as a culturally or socially constructed unit of analysis (Burton 2001; Hackley 2001). One of the stated aims of Critical Marketing is to, rather grandly perhaps, ‘ontologically denaturalise' marketing knowledge (Tadajewski and Brownlie 2008: 10). 
This desire to extent the scholarly remit of marketing from one based primarily on some notion of managerial prescription to one with a broader social, political and ideological concern is not a particularly recent one. Indeed some cultural consumer research and much critical marketing looks back to movements such as Macromarketing and takes inspiration from the critical management studies movement, which had given some attention to marketing practices. From a Critical Management Studies perspective however, marketing is generally considered as a relatively marginal 'specialism' of management somewhat subordinate to the 'core' organizational theory, behaviour and culture (Alvesson 2011). A key priority of Critical Management Studies is to account for and render knowable the power of marketing discourse and then to "suggest how critical approaches can begin to subvert that power" (Morgan 2003: 130). This style of analysis is itself interesting as discourse, especially in terms of how marketing is defined and positioned (against organisational approaches for example). An important objective of critical marketing must be, therefore, to examine ways to design and develop spaces and techniques that enable 'unspoken' wider political and economic assumptions underpinning marketing to be opened up to critical scrutiny (Wensley 2009: 240) while still retaining the capacity to study the nature of markets and marketing from within marketing itself. Critical marketing offers a number of appealing directions for discourse based readings although controversial questions remain over the extent to which the distance that critical marketers seek to establish is actually a separation of some sorts. But while this certainly constitutes a degree of epistemological ambiguity in the critical marketing movement, this should not in itself necessarily limit critical explorations from within and by marketers who see both the progressive potential of discourse analysis in terms of the critical distance it affords, while remaining within the broad disciplinary boundaries of marketing scholarship and marketing theory. 
Discourse analysis not only offers a particular means to investigate marketing and consumption phenomena but also to broaden the realm of enquiry to the level of subject of marketing itself. Through the analysis of discourse, marketing is, as Skalen et al (2008: v) begin, "the object of study rather than our primary theoretical habitat". From a discourse informed approach it is reasonable to re-evaluate some of the early and seminal contributions to the field, such as the debate surrounding Kotler and Levy's (1969) broadening thesis (Luck, 1969) as essentially questions about the legitimate realm of marketing discourse. In many important respects the marketing field, both as a discipline and a profession has been engaged in a wide political and ideological struggle over discourse since its reformation in the 1950s. This is most clearly evident in the rhetorical style of some of the most influential (re)definitions of marketing that date from this period (for example, Drucker 1954, Barwell 1965) and remain important today (Quelch 2009). Discourse based analysis provides an established approach for developing disciplinary reflection on marketing thought and practice, for instance, amongst countervailing discourses on the environment, social development and justice. Discourse analysis here might offer useful descriptions about how the roles, relations and functions of marketing in society have been contested, destabilised, integrated and reformed in discourse (e.g. the 'Societal Marketing Concept' or 'Sustainable Consumption' and 'Green Commodity Discourse' - see Prothero et al., 2010).

Our intention in this paper is to advance the use of discourse analysis both as a critical mirror and methodological lens for marketing and consumer researchers. In this the paper offers a number of key perspectives on discourse and synthesises the methodological applications of these for Marketing and Consumer Researchers. We follow the basic premise of discourse analysts (Fariclough, 1992), that discourse is more than the language used to report on an event; it is not merely a neutral 'vessel', carrying or transmitting information to and from agents in the market. Discourse is an active 'forge', producing the context and content by 
which consumption practices, subjects and relations are knowable in the first instance (Boje et al., 2004; Parker, 1992). Our core rationale is that discourse analytical techniques can and have been used systematically to identify the organisation of marketing knowledge, how these 'enframe' certain subjectivities, practices and relationships, and what the various outcomes are for those subjects of marketing discourses. In this we argue that discourse analysis calls attention to those systems, processes and practices that enable text - such as a marketing textbook or consumer guidebook- to operate in the first place, why it is possible to make certain kinds of statements and not others, why certain values and judgments are attached to specific acts of text and speech, as well as highlighting the fact that some kinds of text (and the agents to which the refer) remain marginalised, discredited and unspoken (Leclercq-Vandelannoitte, 2011). Upon this broad conception of discourse we set about to introduce, position, distinguish and develop discourse analysis as a pathway to disciplinary reflexivity and empirical insight. Whilst we consider this project immediately relevant to critical scholars working in areas such as Consumer Culture Theory (Thompson et al. 2013) and interpretive forms of consumer and marketing research, our goal is to connect with a broader audience where reflection and critical insight may be entirely useful and apt.

\section{Consumption and markets as text}

There was a growing interest in discourse based approaches among some consumer researchers and, to a lesser extent marketing research, in the 1980s and 1990s, following and mirroring a much broader trend in the social sciences and humanities. This movement consisted of both methodological and theoretically orientated proposals and initiatives which all promoted the core idea that language, speech act and text deserved much greater attention and consideration in academic research. This broad movement sought to focus analysis on a range of text and discourse practices, including text production, dissemination and 
communication, and consumption. It also provided a channel through which conceptual developments popular in other academic communities were able to enter the marketing discipline, as well as innovations, including for example, semiotics (Mick, 1986), literary theory (Stern, 1989), reader-response theories (Scott, 1994a), and, one could argue, postmodern and poststructuralist thought more generally (Elliott and Ritson, 1997). These developments provided the core rationale for a much wider range of materials, contexts and methods to be applied in consumer research than had previously been the case which had the effect of raising the importance and significance of culture and cultural practices in marketing and consumer research. Textual approaches to analysis, which had mainly been confined to analysis of written/spoken research text (such as interview data), was extended to include a wider examination of cultural materials and artefacts. Around this time movies and films (e.g. Holbrook and Grayson, 1986), TV shows, and popular fiction all became more widely utilised and analysed as texts of the consumer and markets. Semiotic approaches by Floch (1988) for example effectively treated the Supermarket as a 'text' which could be interpreted as a structuring medium for marketplace relations. These approaches were influential antecedents of discourse research in marketing research today, such as Tuncay Zayer et al's (2012) treatment of popular US television series to investigate representations of gender, domesticity and sexuality.

One of the main fields where textual methods gained rapid application and acceptance in marketing and consumer research was the area of advertising and marketing communications (e.g. McQuarrie and Mick, 1992). Advertising research has, understandably, a long and detailed tradition of analysing and understanding the way that consumers and viewers receive and interpret advertising messages. Only relatively minor adaptations or redefinition of the ad as text, the consumer/receiver as reader, and the agency as author/producer, was needed in order to introduce literary and text-based analysis. This 
translatability of advertising research and text analysis explains why the vast majority of textbased consumer research has focussed on advertising and advertising practice. This preference for analysing advertising text is probably a major factor that has limited the development of more varied approaches to discourse and discourse analysis in other areas of consumer research such as considering other types of text and broader notions of discourse beyond the study of advertisements (Humphreys, 2010a; Kelly et al., 2005).

Most of Stern's analyses use a single print advertisement or a small sample of ads to identify textual elements (literary attributes), the resultant construction of meaning, followed by some kind of deconstruction and critical analysis. In Stern $(1991,1993,1996)$ there is a much greater emphasis placed upon this latter stage, identifying the broader political and ideological consequences of advertising text. Scott's (1994b) support for reader-response has particular resonance because it calls back to an underlying preference in consumer and marketing research to afford some kind of priority or sovereignty to the agent-consumer (or reader). One of the implications of Stern's approach was to de-centre the reader, informed and supported by postmodern theory and ideas. Scott (1994b) can be read as an attempt to synthesize or reconcile text based analysis with a psychological account of consumer (reader) response and behaviour. An exception to this tradition of text analysis of advertising in the marketing area is found in the work of Chris Hackley which seeks to promote a social constructionist ontology to examine marketing and advertising as text (Hackley, 2001: 39). This builds on an extensive tradition of research in communication studies, sociology and cultural studies. Moving away from 'ad-as-text' approach Hackley instead focusses on advertising practice and advertising management as sites of discourse in which social order in advertising agencies is constituted through various discursive and interpretive processes (Hackley, 2001: 243). 


\section{From text analysis to discourse analysis}

Thompson and Haytko (1997) develop a broader view of discourse in explicit terms, defining discourse as "a complex system of cultural meanings that are encoded in conventional ways of talking about fashion". They go on to describe the way in which discourse is used:

"Fashion discourses provide consumers with a plurality of interpretive positions that, because of their diverse associations, can enable them to juxtapose opposing values and beliefs. Consumers use these countervailing meanings of fashion discourse to address a series of tensions and paradoxes existing between their sense of individual agency (autonomy issues) and their sensitivity to sources of social prescription in their everyday lives (conformity issues)."

Discourse is thus presented as a kind of cultural technology which consumers can use, deploy, and exploit to achieve particular outcomes and strategies which, in this case, enable them to create a positive sense of self identity by 'speaking of fashion'. In later work, Thompson (2004) examines market place myths and power discourses in the context of alternative medicine in the US. This paper goes much further in terms of developing a discourse based approach, first by acknowledging the limitations of an ad-centric analysis of text and text-practice and then by explicitly acknowledging the institutional and hegemonic basis for consumer analysis.

"I suggest that critical consumer researchers should study how power relationships operate and shift through institutional discourses and practices" (Thompson, 2004: 174): 
Thompson's approach differs from conventional ad-based readings by beginning with consumer practices and accounts, and does not focus primarily on local structural, semiotic or textual elements of text, considering the influence of wider social discourses on consumer constructions. Thompson and Tian (2008) for example take this further by examining commercial myth as discourse-practice. They conclude with an explicit statement about the limitations of a consumer-agent perspective, calling for what is essentially a discourse approach with a strong 'critical' orientation

One of Thompson's main contributions to the development of discourse analysis in consumer research was to move the focus of analysis away from particular texts and their possible readings to consider discourse in more general and cultural terms. In a similar manner Kozinets (2008) acknowledges the extensive use of narrative, semiotic and text based modes of enquiry in consumer research, but also that terms such as "discourse" and "ideology," are often over-used and poorly, are inconsistently conceptualised, and with ideological and institutional abstractions being conflated with actual representations of cultural texts and in consumers' speech acts.

More recent consumer research has further deconstructed text, narrative and discourse based approaches to develop broader institutional and structural insights into marketing phenomena (Djavlonbek and Varey 2013; Varman et al. 2012). Humphreys (2010a, 2010b) considers the role that 'institutional fields' play in shaping consumption practices and consumer perceptions through and by discourses which influence and frame perceptions and understandings of legitimacy. Rather than being analysed as a character of markets and consumption practice, discourse based approaches are being utilised to examine the processes by which markets are created, shaped and enacted (Bjerrisgaard, and Kjeldgaard 2013). A recurring tension however remains around how to conceptualise and render the power of discourse to shape and frame consumer experience on the one hand (for example Tuncay 
Zayer et al 2012), and the capacity of consumers to utilise the opportunities made possible by the fluid potentiality of discourse to actualise their own identities. There is a broad consensus that consumption and marketplace discourses always retain a certain incomplete, fluid and contested character, and that as social practice these discourses are often most evident when they are analysed as mechanisms of legitimization and performativity. One consequence of these innovations is that it serves to further highlight unresolved and on-going debates about the significance of experience in markets and consumption and the context (or discourse) which facilitates or reproduces these relations (see Askegaard and Linnet 2011).

One of the benefits of these developments in the application of discourse analysis has been to reemphasise synergies between different sub-communities of marketing scholarship. Notwithstanding inevitable tensions, discourse based approaches potentiate links between Consumer Culture Theory, Critical Marketing and Macromarketing become particularly visible, and especially in areas such as sustainability, business ethics, marketing systems and other intersections between marketing and society (see Shultz, 2007). Discourse based approaches have been used to interrogate issues such as environmentalism and green issues (Prothero and Fitchett, 2000; Prothero et al., 2010; Djavlonbek and Varey, 2013) as well as macro approaches to globalisation and neoliberalism. Varman et al. (2012) for example conclude that a failure to reconcile the twin objectives of poverty alleviation and profit maximisation creates a divergence between discourses about policies and marketing activities in developing economies aimed at the 'Bottom of the Pyramid'. In a similar setting Varman et al. (2011) examine the contradictions and difficulties of competing and incompatible discourses that structure debates about the marketization of education in India. More recently Dholakia (2012) has called for a much more explicit integration of macro and critical perspectives in order to achieve progress in the field of marketing. In chime with the discussion here, Dholakia (2012: 223) argues that attempts to create radical and critical 
discourses in marketing have often been sidestepped and stone walled, and that efforts to promote critical-radical approaches within and by marketing scholars are essential. A logical and rational consequence is therefore to further examine and re-state the importance of applying discourse analysis in marketing and to assess the opportunities offered by different types of discourse analysis and Critical Discourse Analysis in particular. Discourse Analysis demonstrates and re-emphasises clear synergies and links within marketing academia, especially between Critical marketing, macromarketing and consumer culture theory.

\section{Orientating Discourse Analysis to Marketing and Consumer Research}

There are a variety of styles and uses of discourse analysis (Alvesson and Karreman. 2000; Phillips and Hardy, 1997) with considerable areas of overlap between. This section seeks to illuminate three key approaches, distinguished by their technical, constitutive and political research orientations (Table 1), and elaborating on the possible ways they might be employed in marketing (Table 2). Table 2 is organised around particular sets of marketing relations (e.g. consumer-product, consumer-marketer, marketing-society/environment). The rationale for this relational categorisation is that discourse constitutes knowledge of subjects in relationships and that, similarly, discourse is both content and relational context (Boje at al., 2004). Interpretations of marketing/consumer discourse do not stand alone from the relational contexts in which they are situated. 


\section{[INSERT TABLE 1 HERE]}

\section{Technical orientation to DA}

First, associated with ethnomethodology and conversation analysis, are approaches where discourse is taken as a technical interaction produced in the skilled accomplishment of everyday social life (Garfinkel, 1967; Gergen 1999; Goffman, 1974; Schegloff, 1992; Sinclair and Coultard, 1975). The unit of analysis - commonly, but not exclusively, 'talk' - is examined through a technical, micro-linguistic lens (Schegloff, 1992), identifying the rules that govern the organisation of talk such as "speech rights" and "turn-taking" (i.e. who may talk next and when). Sinclair and Coultard (1975) identified how rules of "exchange" help teachers and pupils to accomplish the task of learning through conventional sequences in classroom talk: the teacher poses a question (initiates), the pupil answers (response) and the teacher then confirms (feedback). In this technical orientation of DA, consumer researchers would be attuned to grammatical structures like cues, turn-taking, discourse markers (but, however), personal pronouns (me, I), as well as more complex linguistic forms such as juxtapositions (good/bad), rhetorical devices, metaphors (linking concepts), metonyms and even narratives (ideal story types) that organise local consumer texts. These linguistic features are interpreted for the organising function they play in certain market relationships. Rule-bound sequences can be observed readily in customer service relationships where service blueprinting helps both employees and customers to accomplish the task of ordering; “Can I take your order please?" acts as a cue for the customer to respond; "not quite ready" or “yes, I'd like a...." Here we move from a priory assumptions of 'natural', latent customer value, to a view of value as something (also) linguistically organised and produced. 
Whilst this allows for reflection on taken-for-granted 'nature' of marketing phenomena, this technical orientation also lends itself to critical (re)examination of the role of linguistic processes in organising various marketing relations. Extending the example above, by examining the technical features of local customer texts (e.g. customer complaints forms/letters/procedures), analysts might usefully explore how the parameters of customer value are set out and how these demarcate the range of plausible responses from customers. Emerging research into online consumer forums or communities (Kozinets, 2002b) can explore the interactions between marketers and customers or between consumers and other consumers, observing how local speech patterns create rules about who can speak, when, and what can (and cannot) legitimately be said. In marketing pedagogy, a similar technical orientation to DA may enable the tracing of academic marketing discourse.

It should be noted that by adopting a purely technical lens on discourse, it is beyond the methodological scope to explore discourse dynamics much beyond local texts/talk. This approach is focused primarily on interactional functions at the micro-linguistic level of discourse (in $a$ text/speech) are less interesting in the broader question, Why this utterance? Why here? (Billig, 1999; Wetherell, 1998):

"Researchers focus on individual texts, broadly defined, relating them only marginally to the distil context in which they occur or exploring the power dynamics in which they are implicated" (Phillips and Hardy, 2002)

While, for example, it might be wholly insightful to perform a technical DA on the linguistics of Fair Trade or Eco-labelling (or consumer conversations about them), the question of where these linguistic features are drawn from, what social conventions and ideologies are they implicated in are beyond the purview of the analyst. 


\section{Constitutive orientation to $\mathrm{DA}$}

The second cluster of DA picks up on this observation that discourse not only creates rules of talk in local texts but is constitutive of social reality (Berger and Luckmann, 1971; Potter and Wetherell, 1987; Wetherell, 1998). Discourse analysts in this approach adopt a "constructivist position which emphasises the variable constitution of the self in discourse (Fairclough, 1992: 25)" and that this process is enabled by wider discourses:

"The concept of interdiscursivity highlights the normal heterogeneity of texts in being constituted by combinations of diverse genres and discourses....it highlights a historical view of texts as transforming the past -existing conventions, or prior textsinto the present." Fairclough (1995: 134)

This implies that consumers draw upon a nexus of wider social discourses (e.g. love, art, politics, economy, nature, race, relationships, morality) as resources for constituting themselves as certain kinds of subjects in certain kinds of relations to others (Thompson, 2004; Wetherell, 1998). Analysis at this level consequently concerns the situated nature of the text under investigation, not only in terms of who it is produced by and for (locally) but how it is produced (externally) by drawing upon wider social discourses.

The application of this kind of approach in consumer and marketing research has potential in studies of consumer identity and discourse (Roper et al., 2012; Thompson and Haytko, 1997) and is used to examine the meaning of adverts and/or the subject categories and relationships (re)constructed in consumer readings (McQuarrie and Mick, 1992; Scott, 1994a). Thompson (2004) tacitly acknowledges the interdiscursive nature of markets by showing how wider social conventions of health are drawn upon by advertisers and consumers in an attempt to crystallize local interpretations of consumer self-identity. For Critical Marketing this constitutive orientation to DA can be used to explore how subjectivities and associated 
relationships become organised in a range of marketing/consumer texts. Macromarketing researchers interested in how relations between marketing and society have evolved (see Fougère and Skålén 2013) can examine how historical social discourses (e.g. the 'free market', 'economy' and 'social justice') employed in key texts, (re-)constitute certain kinds of marketing-society relations, such as 'social capitalism', 'social marketing', 'sustainable development' or 'ethical consumption'. At a more micro-meso level, DA can be used to investigate the dynamics of emerging market subjectivities such as 'ethical consumers' or 'consumer citizens' (Dobscha and Ozanne, 2001), while observing how these configure new relationships between consumer, product, society and the environment more broadly. How consumers integrate these discourses into their own accounts, how they use them to connect their self to or, contrastingly, disassociate their self from products, brands, corporations, and other consumers (Holt, 2002) are fruitful avenues here. With a concern for content-context dynamics, this orientation to DA also provides marketing research with a means to examine marketing subjectivities and relations within corporations. Discourse Analysis of internal texts such as company reports, missions statements, personal narratives, training programs and recruitment policies, reveal what kinds of subjectivities are constituted in marketing, what kinds of practices and relationships are these connected to, and how marketing discourses are constitutive of 'cross-functional' corporate discourses (See table 2).

\section{Political orientation to $\mathrm{DA}$}

The technical and constitutive orientations to DA can be seen as implicitly critical views in the sense that they challenge functionalist assumptions about marketing subjects independent of discourses that render them knowable in some way. Yet they do not begin with or focus on critical questions. The third strand of DA carries explicitly critical research agendas, with a driving concern for the politics of discourse; as power, control and domination (for example, Moufahim et al. 2007). 
Critical orientations start out with questions; "what 'power effects' are present in discourse?", "how does discourse promote the interests of some subjects and subjugate others?", "how do social realities become taken-for-granted and 'natural'?", "what realities do they conceal?" and finally, "how can DA make visible or 'de-naturalise' discourses of power?"

"By denaturalizing the discursive practices and the texts of a society....and by making visible and apparent that which may previously have been invisible and seemingly natural, they intend to show the imbrication of linguistic-discursive practices with the wider socio-political structures of power and domination.” (Kress, 1990: 85)

Stemming from a rich critical tradition in sociology, this third 'critical' strand of DA concerns itself with the construction, maintenance and concealment of domination and control (van Dijk, 1997; Lutz and Collins, 1993; Kress, 1990) and is applicable to a range of critical marketing questions. In exploring market-society relations, for example, Schroeder and Borgerson (1999) show how marketing texts commodify Hawaii for western tourist consumers by drawing upon a dominant paradisal, neo-colonial discourses of the 'exotic other'. The interpretation (historically) reinforced for the tourist, represents Hawaiians in relatively disempowered relations with tourists; as naïve, economically weak and sexually submissive 'native' subjects. Consumer-environmental relations are equally rich contexts for CDA, with analysts attuned to the ways in which marketers integrate (marginal) eco-centric discourses with more dominant 'commodity discourses' (e.g. value, utility, distinction) in attempts to mainstream green consumption practices (Prothero and Fitchett, 2000). Analysts exploring consumer-producer relationships in the marketing of 'Fair Trade' might ask; "How do Fair Trade texts co-opt producers of products and services?", "is Fair Trade really fair 
(and for whom)?"; "If producers become empowered or, in fact, instrumentalized in novel ways?", or even "If relations of power are merely reallocated to less visible market relations?" (Davies and Crane, 2003).

In positioning critical approaches to discourse analysis amidst technical and constitutive approaches (Table 1) we are able to distinguish between sets of assumptions, questions and possible applications of critical and non-critical discourse analysis (Table 2). We now wish to elaborate on a suitably critical exemplar of DA - Critical Discourse Analysis - drawing out core concerns of this approach and linking to Critical Marketing research.

[INSERT TABLE 2 HERE]

\section{Framing Critical Discourse Analysis for Marketing}

In this section we elaborate on the key elements of an explicitly critical approach to discourse analysis, drawing upon contributions from sociology, consumer and organisational research.

\section{Consumption texts as dialectic sites}

Critical approaches to DA (Covaleski et al., 1998; Gustavsson, and Czarniawska, 2004;

Fairclough, 1995; 2009; Keenoy, and Oswick, 2002; Leclercq-Vandelannoitte, 2011;

Livesey, 2001; Parker, 1992; Phillips and Hardy, 1997) are commonly concerned with how subjectivities are produced in texts such that: "When we discourse analyse a text, we need to ask in what ways...the discourse is hailing us, shouting 'hey you there' and making us listen as a certain type of person." (Parker, 1992) Crucially, for critical discourse analysts, this 
process is viewed as a dialectic one, where identities and relations are contested (Covaleski et al., 1998; Fairclough, 1995, 2009; Lutz and Collins, 1993) amidst countervailing discourses of power. Text is the interpretable operation of discursive struggle, rendering interview transcripts, online consumer forums, websites, avatars, guidebooks, shopping signage and labelling, adverts, customer feedback devices, product and corporate branding, consumer diaries, field notes, marketing textbooks and many more as dialectic sites of conflict, contestation, power, hegemony, resistance and transformation.

This is illustrated by Livesey (2001) who employs CDA to interpret an oil company's advertorials (text) aimed at galvanising consumer resistance to climate change regulation. ExxonMobil draws upon dominant social discourses of the economy, of capitalism, American freedom, democracy and 'free markets', which as dominant social discourses (compared to fringe discourses on sustainability and climate change) have powerful persuasive effects on the consumer audience. Multiple identities are evoked and dichotomized into subjects that are problematic (climate scientists \& governments) and those that are ideal (the economy, consumers, Americans). Climate scientists and governments, for instance, are portrayed as misguided and non-rational subjects- posing a potent threat to the health of the US economy, personal freedom and the American way of life more broadly. The interpretive context constructed in this dialectic hails to consumers (Parker, 1992), as hardworking, economically concerned patriots, to "reject climate regulation and keep filing up your cars at the pump!" In this sense, texts are considered sites of power, struggle and control, where certain interpretations are privileged (e.g. the status quo) and directed to particular courses of actions, whilst others (e.g. regulatory shift) are concealed from the purview of consumers.

Relations of power in consumer discourse 
CDA researchers are concerned with how power is distributed unequally between subjects in discourse (Covaleski, 1998; Leclercq-Vandelannoitte , 2011; Livesey, 2001; Lutz and Collins, 1993; Parker, 1992; Phillips and Hardy, 1997). This approach recognises that consumer identities are constructed as being subject to disciplinary norms that promote conformity to a norm/rule and preclude non-normative practices. A focal point for analysts is to examine the asymmetrical distribution of power between subjects around such norms. Power may be interpreted by analysts along different relational axes (see Table 2.) and between subjects who are present as well as those ostensibly absent from the same discourse.

This is observed in Caruana et al's., (2008) CDA of the 'Independent' tourism market where consumers are normalised as highly autonomous subjects in the discourse of 'backpacker travel' guidebooks. Constructed as subjects of a normative set of selfdetermined, 'independent' practices, consumers are instructed to roam anywhere (off-thebeaten-track), seek out 'authentic' local people and avoid mainstream tourists (i.e. the normative practices of 'independent subjects'). CDA revealed relations of power flowing in different relational directions. First, guidebooks instrumentalized relations between tourists and local people, with the latter acting as mere markers of authenticity and self-distinction for the tourist. Second, they denigrated other types of 'commercial' tourism subjects as morally redundant and largely excluded from real, authentic experiences. Third, they show how the consumer's use of an 'independent guidebook' - a toolkit for 'how to do' independent tourism- paradoxically engenders dependency in tourist's relations with the market. Whilst Critical Marketing is broadly concerned with how one party is dominated in some way by another, CDA, as both a practicable and political methodology, aims to show how this apparent social arrangement is achieved in discourse as a basis for contestation, struggle and social change (Fairclough, 1995; 2009). 


\section{Epistemology, hegemony and change}

This last point raises an important epistemological debate about the extent to which discourse a) fixes subjectivities and power relations - a structuralist, 'Big D' Marxist view of discourse (Heracleous and Barrett, 2001); b) produces subjectivities and relations that can be adopted, resisted and transformed - a critical realist view of discourse (Fairclough at al, 2004, and 'later' Foucault, 1994) and c) a more interpretive 'small d' view of discourse as a socially constructed, contextually situated process of meaning-making and power relations (Caruana and Crane, 2008; Thompson, 2004). These epistemological positions implicate tensions between text and agency:

"Whereas 'little ' $d$ ' discourse is criticized for overestimating the power of social actors in local discourse and overlooking the constituting power of larger Discourses ... big ' $\mathrm{D}$ ' Discourse draws criticism for being Discourse-deterministic and thus minimizing agency"” (Leclercq-Vandelannoitte , 2011: 1248)

Epistemological distinctions are important issues, connecting with key topics in CM such as consumer emancipation and resistance. Whilst some consider consumers to be 'trapped inside' market discourse, (Holt, 2002; Kozinets, 2002a), others more explicitly assert that consumers can contest, redefine and 'open up' seemingly dominant social discourses (Thompson, 2004).

\section{Opening up consumer discourse}

Knights and Morgan, (1991: 262) ask "How is it that alternative ways of seeing organizations are negated, undermined and destroyed by corporate strategy discourse?”. Its 
'de-naturalising' agenda (Kress, 1990) renders CDA uniquely poised to help analysts understand how marketing discourse renders certain consumer realities 'seeable', whilst others 'unseeable'. Caruana and Crane (2008), for instance, show how the marketing discourse of 'Responsible Tourism' depicts tourist practices and relations with local people and ecosystems as responsible, 'trouble and guilt-free'. This mythologized view of the responsible tourist subject both creates and obscures new ethical tensions from the consumer's view. The implication is that consumer discourse, as a version of reality offered up for interpretation, can be simultaneously a 'way of seeing' and 'a way of not seeing'. CDA can be used here to highlight paradox and contradiction as well as the processes that sustain their subversion.

Beyond marketing practice, the disciplines of marketing and consumer behaviour are also naturalising and thus potentially subverting discourses. On the one hand marketing textbooks appear as 'real' case-study reflections of empirical observations of markets, consumers and practitioners, instructing a set of logical strategic responses from certain subjects. Yet at the same time, the discipline - as a conventional 'way of knowing' markets and 'being marketers' - is essentially constituted by and from a constellation of heuristic devices, concepts and definitions that reify marketing as a self-evidently natural subject (Hackley, 2003). This natural 'way of seeing' marketing (e.g. as a commodity distribution technique) simultaneously becomes a 'way of not seeing' marketing (e.g. as a social practice). The view of CDA is that by exploring the constraining effects of marketing discourse and revealing its' constructed (and therefore contestable) nature, consumer discourse may be opened up to novel definitions, interpretations, questions and practices. 


\section{Conclusions}

Discourse analysis, and CDA in particular, offers a valuable methodological and epistemological direction for marketers who, while willing to subject the mainstream marketing discourse to scrutiny and analysis are also able to examine some of the reasons why dominant discourses about marketing remain powerful and widely accepted. The common aim of both critical marketing research and CDA to ontologically de-naturalise marketing theory should not be understood as either a requirement to necessarily neutralise or negate it. While CDA analysts "should at the same time be aware that their work is constantly at risk of appropriation by the state and capital" (Fairclough et al 2011:374) this awareness should not exclude them from applying CDA to explore these issues. The 'risk' of appropriation, if indeed there is deemed to be one, should not, in our view, dissuade discourse analysis research in marketing scholarship. Thompson (2004) makes a clear concluding statement on this point, urging marketing and consumer researchers to retain a militantly agnostic perspective when evaluating these types of critical criteria. The primary objective of discourse analysis is to unpack and make explicit assumptions and norms that might otherwise remain naturalised and therefore beyond critique, especially those concerning power relations.

The disciplinary tradition of marketing and consumer research has meant that researchers have not tended to be skilled in textual analysis, literary methods and linguistics, as compared to the wide use of statistics, modelling and qualitative methodologies. One important aspect of CDA is that it does not prioritise a close scrutiny and dissection of the linguistic structure of particular words, phrases and grammar. It is far more focussed on the play of language and texts more generally, both in terms of their use and appearance as well as in terms of their consequences and practice. This broader view opens up a whole range of 
empirical, conceptual and ethical questions, for instance, concerning the cultural functions of various marketing texts, how consumers and marketers construct and are constructed in them, how important objects and relationships are legitimized and sustained and how power relations operate therein.

Discourse Analysis approaches start off from the expectation that there is no essential 'market', 'consumer' or 'marketing', but that these objects are constituted in many ways and in many different types of discourse. As Humphreys (2010b) demonstrates, analysis of discourse can illustrate market-making and creation, i.e. as products of certain discourse practices. This means that researchers need to be prepared to treat potentially all of their research objects in a more contingent manner. For instance, CDA is less concerned with questions about whether consumers really are active or passive and more with the reasons why and how these particular representations of the consumer have become popular and resonant, rather than others. Djavlonbek and Varey (2013) illustrate these kinds of outcomes in their examination of green consumer behaviour, showing how meaning structures (interaction and discourse) in this context reproduce inconsistent behaviour as necessary and practical outcomes of a market structure.

A key aspect of CDA is the idea that discourses emerge from micro-level practices, or to put it another way, they are a 'bottom up' phenomenon that derive from everyday conditions and practices. Discourse analysis does not imply a deterministic or structuralist view of the world, that somehow the 'discourse of the market' causes people, institutions and organisations to conform and behave in certain kinds of ways. One could quite rightly ask, where do these all-powerful discourses come from, and who is responsible for their propagation? Discourse analysis shows how modern marketing ideology developed 'from below' in certain microtechniques which emerged in institutions such retailing, print 
advertising and marketing research. This is probably one of the most exciting and transformative aspects of CDA for marketing because it opens up the possibility of examining marketing ideology and discourse through analysis of everyday, common-place activities and processes. Analysis of marketing produced literature and initiatives, marketing management practices, consumer policies and products, for example, can all be seen as much more than simply indicative of a 'wider' ideology, but rather as part of the constitution of this discourse more generally. Analysis of marketing 'text' is not merely indicative; it is discourse production in action.

\section{References}

Alvesson, M. and Karreman, D. (2000), "Varieties of discourse: on the study of organizations through discourse analysis", Human Relations, Vol. 53 No.9, pp.1125-1149.

Alvesson, M. (ed), (2011) Classics in Critical Management Studies, Cheltenham, Edward Elgar.

Arnould, E.J. and Thompson, C.J (2005) Consumer Culture Theory (CCT): Twenty Years of Research, Journal of Consumer Research 31, 868-82.

Askegaard, S. \& Linnet, J. T. (2011), “Towards an epistemology of consumer culture theory: Phenomenology and the context of context”, Marketing Theory, Vol. 11, no.4, pp.381-404

Barwell, C. (1965) The Marketing Concept' in Wilson, A. (ed.), The Marketing of Industrial Products: London: Hutchinson.

Berger, P. and Luckmann, T. (1971), The social construction of reality: a treatise in the sociology of knowledge, Harmondsworth, Penguin. 
Billig, M. (1999), "Whose Terms? Whose Ordinariness? Rhetoric and Ideology in Conversation Analysis", Discourse Society, Vol. 10 No. 4, pp. 543-558

Bjerrisgaard, S.M, and Kjeldgaard, D. (2013) “How Market Research Shapes Market Spatiality: A Global Governmentality Perspective", Journal of Macromarketing, Vol. 33, pp. $29-40$.

Boje, D., Oswick, C. and Ford, J. (2004), "Language and Organization: The Doing of Discourse", Academy of Management Review, Vol. 29 No. 4, pp.571-577.

Borgerson, J.L. and Schroeder. J.E. (2002), "Ethical Issues of Global Marketing: Avoiding Bad Faith in Visual Representation," European Journal of Marketing, Vol. 36, No.5, pp.570594

Brownlie, D., Saren, M., Wensley, R. and Whittington, R. (1999) Rethinking Marketing. Sage.

Burton, D. (2001) "Critical marketing theory: the blueprint?", European Journal of Marketing, Vol. 35 Iss: 5/6, pp.722 - 743

Caruana, R, Crane A. and Fitchett, J.A. (2008), "Paradoxes of Consumer Independence: A Critical Discourse Analysis of The Independent Traveller”, Marketing Theory, Vol. 8 No. 3, 253-272.

Caruana, R. and Crane, A. (2008), "Constructing consumer responsibility: exploring the role of corporate communications”, Organization Studies, Vol. 29 No. 12, pp. 1495-1519

Caruana, R. and Crane, A. (2011) “Getting away from it all: Exploring Freedom in Tourism,' Annals of Tourism Research, 34(4): 1495-1515.Covaleski, M. A. Dirsmith, M., Heian, J. B. and Sajay, S. (1998), “The calculated and the avowed: Techniques of discipline and struggles 
over identity in the Big Six public accounting firms, Administrative Science Quarterly, Vol. 43, pp.293-327.

Davies, I.A. and Crane, A. (2003), "Ethical Decision Making in Fair Trade Companies", Journal of Business Ethics, Vol. 45, no. 1-2, pp.79 - 92.

Dholakia, N. (2012), "Being Critical in Marketing Studies: The Imperative of Macro Perspectives”, Journal of Macromarketing, Vol. 32 No.2, pp. 220-225.

Djavlonbek, K. and Varey R. (2013) Neo-structuralist analysis of green-marketing discourse: interpreting hybrid car manufacturers and consumers, Consumption Markets \& Culture, 16(3) 266-289.

Dobscha, S. and Ozanne, J. L. (2001), “An ecofeminist analysis of environmentally friendly women using qualitative methodology: the emancipatory potential of an ecological life," Journal of Public Policy and Marketing, 20(2), pp. 201-214.

Drucker, P. (1954) The Practice of Management, New York: Harper \& Brothers.

Elliott, R. and Ritson, M. (1997), “ Poststructuralism and the Dialectics of Advertising:

Discourse, Ideology, Resistance", in S. Brown and D. Turley (eds.) Consumer Research: Postcards from the Edge. London: Routledge, pp.190-219.

Ellis, N., Fitchett, J., Higgins, M., Jack, G., Lim, M., Saren, M. \& Tadajewski, M. (2011), Marketing: A Critical Textbook. Sage.

Fairclough, N. (1992), Discourse and Social Change. Cambridge: Polity.

Fairclough, N. (1995), Critical Discourse Analysis: The Critical Study of Language. London: Longman. 
Fairclough, N. (2009) “A Dialectical-Relational Approach to Critical Discourse Analysis in Social Research.” In Wodak, R., and Meyer, M. (eds), Methods of Critical Discourse Analysis, London, Sage.

Fairclough, N., Mulderrig, J. and Wodak, R. (2011) Critical Discourse Analysis, in Teun A Van Dijk (ed.) Discourse Studies: A Multidisciplinary Introduction, London: Sage, pp. 357378.

Fairclough, N., Jessop, B., \& Sayer, A. (2004), “Critical realism and semiosis.” In Jonathan Joseph \& John Roberts (eds.) Realism, Discourse and Deconstruction. Routledge: London, UK, 23-42.

Floch, J.M. (1988), “The contribution of structural semiotics to the design of a hypermarket.”, International Journal of Research in Marketing, Vol. 4 No.3, pp. 233-252 Foucault, (1994), “The ethic of care for the self as a practice of freedom”, In J. Bernauer \& D. Rasmussen (Eds.), The Final Foucault. Cambridge, MA: MIT Press.

Fougere, M. and Skalen, P. (2013), "Extension in the Subjectifying Power of Marketing Ideology in Organizations: A Foucauldian analysis of Academic Marketing”, Journal of Macromarketing, Vol. 22. No. 1, 13-28.

Garfinkel, H. (1967), Studies in Ethnomethodology, Englewood Cliffs. New Jersey: Prentice Hall.

Gergen, K. (1999), An invitation to social construction, London, Sage.

Goffman, E. (1974) Frame analysis, New York: Harper Colophon Books.

Gustavsson, Eva., and Barbara Czarniawska (2004), "Web woman: the on-line construction of corporate and gender images", Organization, Vol.11 No.5, pp.651-670. 
Hackley, C. (2001), Marketing and Social Construction: Exploring the Rhetorics of Managed Consumption, London, Routledge.

Hackley, C. (2003), “ “We Are All Customers Now”: Rhetorical Strategy and Ideological Control in Marketing Management Texts”, Journal of Management Studies. Vol. 40 No.5, pp. $1325-1352$.

Heracleous, L. and Barrett, M. (2001), “Organizational change as discourse: communicative actions and deep structures in the context of information technology implementation," Academy of Management Journal, Vol. 44, No.4, pp. 755-778.

Holbrook, M.B. and Grayson, M.W. (1986), “The semiology of cinematic consumption: symbolic consumer behavior in Out of Africa”, Journal of Consumer Research, Vol. 13 (December), pp.374-381.

Holt, D. (2002), "Why do brands cause trouble? A dialectical theory of consumer culture and branding", Journal of Consumer Research, Vol. 29 No. 1, pp. 70-91.

Humphreys, A. (2010a) "Semiotic Structure and the Legitimation of Consumption Practices: The Case of Casino Gambling, Journal of Consumer Research, Vol. 37, No. 3, pp. 490-510 Humphreys, A. (2010b) “Megamarketing: The Creation of Markets as a Social Process”, Journal of Marketing, Vol. 74, March, pp. 1-19.

Kelly, A., Lawlor, K. \& O'Donohoe, S. (2005), “Encoding Advertisements: The Creative Perspective", Journal of Marketing Management, Vol. 21, No. 5/6, pp. 505-528

Keenoy, T., and Oswick, C. (2002) "Discourse, organising and identity: Some theoretical and methodological implications". Management Research News, 25: 104-106. 
Knights, D. and Morgan, G. (1991) “Corporate strategy, organisations, and subjectivity: A critique. Organisation Studies," 12: 251-273.

Kotler, P. and Levy, S.J. (1969), "Broadening the Concept of Marketing”, Journal of Marketing, Vol. 33, pp.10-16.

Kozinets, R. V. (2002a), “Can consumers escape the market? Emancipatory illuminations from Burning Man”. Journal of Consumer Research, Vol. 29, pp.20-38.

Kozinets, R. V. (2002b), "The Field Behind the Screen: Using Netnography for Marketing Research in Online Communities," Journal of Marketing Research, 39, 1 (February), pp. 6172.

Kozinets, R.V. (2008), “Technology/Ideology: How Ideological Fields Influence Consumers' Technology Narratives', Journal of Consumer Research, Vol. 34 No.6, pp.865-881.

Kress, G. (1990), "Critical Discourse Analysis”, Annual Review of Applied Linguistics, Vol. 11, pp. 84-99.

Leclercq-Vandelannoitte , A. (2011), “Organizations as Discursive Constructions: A Foucauldian Approach”, Organization Studies, Vol.32 No.9, pp.1247-1271.

Livesey, S.M. (2001), "Eco-identity as discursive struggle: Royal Dutch Shell, Brent Spar, and Nigeria", The Journal of Business Communication, Vol. 38, pp. 58-91.

Luck, D.J. (1969), “Broadening the Concept of Marketing: Too Far”, Journal of Marketing, Vol. 33 (July), pp.53-55

Lutz C. A. and Collins J. L. (1993), Reading National Geographic, Chicago: University of Chicago Press. 
Marion, G. (2006), Research Note: Marketing ideology and criticism: Legitimacy and legitimization, Marketing Theory, Vol. 6 No.2, pp.245-262.

Maclaran P, Saren M, Stern, B and Tadajewski M (eds) (2009) The Sage Handbook of Marketing Theory, Sage Publications, London.

McCracken, G. (1988) Culture and Consumption: New Approaches to the Symbolic Character of Consumer Goods and Activities, Indiana University Press, Bloomington, IN.

McQuarrie, E.F. and Mick, D.G. (1992), “On Resonance: A Critical Pluralistic Inquiry into Advertising Rhetoric”, Journal of Consumer Research, Vol.19 (September), pp.180-197.

Mick, D.G. (1986), “Consumer Research and Semiotics: Exploring the Morphology of Signs, Symbols and Significance", Journal of Consumer Research, Vol.13 (September), pp.196-214.

Morgan, G. (2003) Marketing and Critique: Prospects and Problems, in Alvesson, M. and Willmott, H. (eds), Studying Management Critically, Chapter 6, London, Sage, 111-131.

Moufahim, M., Humphreys, M., Mitussis, D., and Fitchett, J.A. (2007), “Interpreting Discourse: A Critical Discourse Analysis of the Marketing of an Extreme Right Party", Journal of Marketing Management, Vol. 23, No. 5-6, pp. 537-558.

Parker, I (1992), Discourse Dynamics, London, Routledge.

Phillips, N. and Hardy, C. (1997), "Managing multiple identities: discourse legitimacy and resources in the UK refugee system", Organisation, Vol. No. 2, pp. 159-185.

Potter, J. and Wetherell, M. (1987), Discourse and Social Psychology: Beyond Attitudes and Behaviour, London: Sage.

Prothero, A., McDonagh, P. and Dobscha, S. (2010), Is Green the New Black? Reflections on a Green Commodity Discourse, Journal of Macromarketing, Vol.30 No.2, pp 147-159. 
Prothero, A. and Fitchett, J. A. (2000), “Greening capitalism: opportunities for a green community," Journal of Macromarketing, Vol. 20 No.1, pp. 46-56.

Quelch, J. (2009) 'In praise of marketing', Harvard Business School: Working Knowledge Series, February 5, 2009, http://hbswk.hbs.edu/item/6015.html

Roper, S. Caruana, R, Medway, D. and Murphy, P. (forthcoming), "Constructing luxury brands: exploring the role of consumer discourse", European Journal of Marketing,

Sacks, H., Schegloff, E. and Jefferson, G. (1974), “A simplest Systematics for the Organization of Turn-Taking in Conversation”, Language, Vol. 50, pp.696-735.

Schegloff, E. A. (1992), “In Another Context”, In A. Duranti and C. Goodwin (eds.)

Rethinking Context, Cambridge: Cambridge University Press, pp.191-229.

Schroeder, J. and Borgerson, J. (1999), "Packaging paradise: Consuming Hawaiian music," Advances in Consumer Research Vol. 26: 46-50.

Scott, Linda M. (1994a), "Images in Advertising: The Need for a Theory of Visual Rhetoric", Journal of Consumer Research, Vol. 21 no. 2, pp. 252-273

Scott, L.M. (1994b), “The Bridge from Text to Mind: Adapting Reader-Response Theory to Consumer Research”, Journal of Consumer Research, Vol. 21 No.3, pp.461-48.

Shankar, A., Cherrier, H. and Canniford, R. (2006), "Consumer Empowerment: A Foucauldian Interpretation,” European Journal of Marketing, Vol.40, No.9/10, pp.1013-1030.

Shultz, D. (2003) "Marketing gets no respect in the boardroom” Marketing News, Vol. 37 No.24, 9 
Shultz, Clifford J. II. (2007). “Macromarketing,” in Explorations of Marketing in Society, Gundlach, G., L. Block, and Wilkie, W. (eds.), Cincinnati, OH: South-Western / Thomson, 766-784.

Sinclair, J. and Coulthard, M. (1975), Towards An Analysis of Discourse: The English used by Teachers and Pupils, Oxford: Oxford University Press.

Skålén, P., Fellesson, M. and Fougère, M. (2008), Marketing Discourse: A Critical Perspective, Routledge.

Skålén, Per (2010), “A discourse analytical approach to qualitative marketing research", Qualitative Market Research: An International Journal, Vol. 13 No.2, pp.103-109.

Stern, B.B. (1989), "Literary Criticism and Consumer Research: Overview and Illustrative Analysis", Journal of Consumer Research, Vol. 16 No. 3, pp.322-334.

Stern, B.B. (1991), "Who Talks Advertising? Literary Theory and Narrative Point of View", Journal of Advertising, Vol. 20. No.3, pp. 9-22.

Stern, B.B. (1993), "Feminist Literary Criticism and the Deconstruction of Ads: A Postmodern View of Advertising and Consumer Responses”, Journal of Consumer Research, Vol. 19 No. 4, pp. 556-566.

Stern, B.B. (1996), "Textual Analysis in Advertising Research: Construction and Deconstruction of Meanings" Journal of Advertising, Vol. 25 No. 3, pp. 61-73. Thompson, C.J. (2004), “Marketplace Mythology and Discourses of Power”, Journal of Consumer Research, Vol. 31 No.1, pp.162-180, 
Thompson, C.J., Arnould, E. and Giesler, M. (2013) "Discursivity, difference, and disruption: Genealogical reflections on the consumer culture theory heteroglossia", Marketing Theory, Vol. 11.

Thompson, C and Tian, K. (2008), "Reconstructing the South: How Commercial Myths Compete for Identity Value through the Ideological Shaping of Popular Memories and Countermemories," Journal of Consumer Research, Vol. 34 No.5, pp. 595-613.

Thompson, C.J. Haytko, D.L. (1997), “Speaking of Fashion: Consumers' Uses of Fashion Discourses and the Appropriation of Countervailing Cultural Meanings”, Journal of Consumer Research, Vol. 24 No.1, pp.15-42.

Tuncay Zayer, L., Sredl, K., Parmentier, MA, and Coleman, C (2012), “Consumption and Gender Identity in Popular Media: Discourses of Domesticity, Sexuality and Authenticity," Consumption, Markets, and Culture, Vol. 15, No. 4.

Van Dijk, T. (1997), “Analysing Discourse Analysis”, Discourse and Society, Vol.8 No.1, 56. Varman, R., Skålén, P., and R. Belk (2011), "Conflicts at the Bottom of the Pryamid: Profitability, Poverty Alleviation, and Neoliberal Governmentality", Journal of Public Policy \& Marketing, Vol. 31, No.1, pp.19-35

Wetherell, M. (1998), "Positioning and interpretative repertoires: Conversation analysis and poststructuralism in dialogue", Discourse and Society, Vol. 9 No. 3, pp. 387-412. 


\section{Table 1. ORIENTATIONS IN DISCOURSE ANALYSIS}

\begin{tabular}{|c|c|c|c|c|c|}
\hline $\begin{array}{l}\text { Characterising } \\
\text { orientations to } \\
\text { discourse }\end{array}$ & Methods & $\begin{array}{c}\text { Ontological } \\
\text { assumptions }\end{array}$ & $\begin{array}{l}\text { Level of } \\
\text { discourse }\end{array}$ & $\begin{array}{l}\text { Main unit of } \\
\text { analysis }\end{array}$ & Focus /aim \\
\hline $\begin{array}{c}\text { Technical } \\
\text { (Sacks, Schegloff) }\end{array}$ & $\begin{array}{l}\text { Conversation and } \\
\text { micro-linguistic } \\
\text { analysis }\end{array}$ & Objective reality & $\begin{array}{l}\text { Local, internal } \\
\text { (micro) }\end{array}$ & $\begin{array}{l}\text { Spoken discourse } \\
\text { 'talk' }\end{array}$ & $\begin{array}{l}\text { Uncovering local } \\
\text { rules organising } \\
\text { social behaviour }\end{array}$ \\
\hline $\begin{array}{c}\text { Constitutive } \\
\text { (Potter, Wetherell) }\end{array}$ & $\begin{array}{c}\text { Discursive } \\
\text { psychology, } \\
\text { semantic, form- } \\
\text { meaning analysis }\end{array}$ & $\begin{array}{l}\text { Socially constructed } \\
\text { meanings }\end{array}$ & $\begin{array}{l}\text { Local-contextual } \\
\text { (micro-meso) }\end{array}$ & $\begin{array}{l}\text { Spoken, written, } \\
\text { visual discourse }\end{array}$ & $\begin{array}{l}\text { How subjects } \\
\text { constitute meanings } \\
\text { from wider } \\
\text { discourse }\end{array}$ \\
\hline $\begin{array}{c}\text { Power } \\
\text { (Foucault, Marx) }\end{array}$ & $\begin{array}{c}\text { Macro social } \\
\text { critique, political } \\
\text { theory }\end{array}$ & $\begin{array}{l}\text { Objective, } \\
\text { structuring of } \\
\text { systems of } \\
\text { domination }\end{array}$ & $\begin{array}{c}\text { Global 'meta } \\
\text { structures' } \\
\text { (Macro) }\end{array}$ & $\begin{array}{l}\text { Spoken, written, } \\
\text { visual discourse, } \\
\text { architecture } \\
\text { (everything) }\end{array}$ & $\begin{array}{l}\text { The hegemonic } \\
\text { effects of social- } \\
\text { historical discourses }\end{array}$ \\
\hline \multicolumn{6}{|c|}{ ORIENTATIONS IN DISCOURSE ANALYSIS } \\
\hline \multicolumn{6}{|c|}{ *This table serves as a heuristic device to help Marketing and Consumer Researchers to conceptualise the different approaches to Discourse Analysis. } \\
\hline
\end{tabular}


Table 2: Applying DA: A Critical Lens for Marketing Research

\begin{tabular}{|c|c|c|c|c|}
\hline Market relations & $\begin{array}{c}\text { Example } \\
\text { questions for } \\
\text { CM }\end{array}$ & Possible texts & $\begin{array}{l}\text { Indicative } \\
\text { outcomes }\end{array}$ & User audiences \\
\hline Consumer-product & $\begin{array}{l}\text { How central is the } \\
\text { consumer in the product? } \\
\text { Are products and brands } \\
\text { co-created? }\end{array}$ & $\begin{array}{l}\text { Marketing textbooks, } \\
\text { consumer forums, adverts, } \\
\text { product terms and } \\
\text { conditions }\end{array}$ & $\begin{array}{l}\text { Assessment of the gaps } \\
\text { between the rhetoric and } \\
\text { practice of consumer } \\
\text { sovereignty. Where do } \\
\text { consumers actually co- } \\
\text { create value - if at all? }\end{array}$ & $\begin{array}{l}\text { Customer values, co- } \\
\text { creation and consumer } \\
\text { sovereignty literatures }\end{array}$ \\
\hline Consumer-market & $\begin{array}{l}\text { How is consumption } \\
\text { influenced by the } \\
\text { institutional context of the } \\
\text { market? }\end{array}$ & $\begin{array}{l}\text { Consumer accounts, } \\
\text { marketing textbooks, } \\
\text { professional marketing } \\
\text { charters, government } \\
\text { consumer policies }\end{array}$ & $\begin{array}{l}\text { - Assessment of how } \\
\text { academic definitions of } \\
\text { marketing roles shape } \\
\text { consumer practice. } \\
\text {-Marketers as 'cultural } \\
\text { brokers/authorities' of } \\
\text { consumer knowledge. } \\
\text { - How do marketing } \\
\text { communications constrain } \\
\text { consumer choice? }\end{array}$ & $\begin{array}{l}\text { Marketing education, } \\
\text { consumer sovereignty, } \\
\text { critical marketing \& } \\
\text { consumer culture theory } \\
\text { literatures. }\end{array}$ \\
\hline $\begin{array}{l}\text { Consumer- } \\
\text { consumer }\end{array}$ & $\begin{array}{l}\text { How are consumer- } \\
\text { consumer relationships } \\
\text { managed in markets? } \\
\text { How do some consumers } \\
\quad \text { subvert others? }\end{array}$ & $\begin{array}{l}\text { Customer profiling/ } \\
\text { segmentation and } \\
\text { stratification texts. } \\
\text { Consumer diaries, focus } \\
\text { group interview transcripts, }\end{array}$ & $\begin{array}{l}\text { Explanations of how \& } \\
\text { certain consumers are } \\
\text { included/excluded from } \\
\text { markets(segments)? } \\
\\
\text { Brands as tools for social } \\
\text { signification (e.g. 'in } \\
\text { group/out grou'), } \\
\text { bullying, social exclusion } \\
\text { and violence between } \\
\text { consumers. }\end{array}$ & $\begin{array}{c}\text { Branding, social } \\
\text { marketing, segmentation } \\
\text { and consumer vulnerability } \\
\text { as well as critical } \\
\text { marketing literatures. }\end{array}$ \\
\hline $\begin{array}{l}\text { Consumer- } \\
\text { producer }\end{array}$ & $\begin{array}{l}\text { How do consumption } \\
\text { practices co-opt producers } \\
\text { of products and services? }\end{array}$ & $\begin{array}{l}\text { Customer service scripts, } \\
\text { consumer guidebooks, } \\
\text { consumer diaries, } \\
\text { advertisements. }\end{array}$ & $\begin{array}{l}\text { Assessment of how texts } \\
\text { organise social categories } \\
\text { in ways that position } \\
\text { consumers and producers } \\
\text { in ways that privilege the } \\
\text { choices and actions of one } \\
\text { over the other. } \\
\text { How these are naturalised, } \\
\text { legitimised and } \\
\text { uncontested? }\end{array}$ & $\begin{array}{l}\text { Consumer culture theory, } \\
\text { critical marketing, } \\
\text { marketing \& business } \\
\text { ethics literatures. }\end{array}$ \\
\hline $\begin{array}{l}\text { Marketer- } \\
\text { consumer }\end{array}$ & $\begin{array}{l}\text { How do consumers and } \\
\text { marketers use power to } \\
\text { influence each other? }\end{array}$ & $\begin{array}{l}\text { Customer complaints } \\
\text { cards, consumer forums, } \\
\text { adverts, consumer } \\
\text { narratives, concealed } \\
\text { product augmentations. }\end{array}$ & $\begin{array}{l}\text { How consumers use texts } \\
\text { to subvert specific } \\
\text { marketing messages or } \\
\text { forward macro criticisms } \\
\text { of markets (e.g. Adbusters) } \\
\\
\text { Illustration of the implicit } \\
\text { misleading of consumers } \\
\text { regarding potential price or } \\
\text { risks of a product (e.g. } \\
\text { small print). }\end{array}$ & $\begin{array}{c}\text { Marketing and business } \\
\text { ethics, critical marketing } \\
\text { and management, } \\
\text { advertising and marketing } \\
\text { communications \& } \\
\text { consumer culture theory } \\
\text { literatures. }\end{array}$ \\
\hline $\begin{array}{l}\text { Marketer- } \\
\text { corporation }\end{array}$ & $\begin{array}{l}\text { How are functional } \\
\text { activities constrained by } \\
\text { corporate agendas? }\end{array}$ & $\begin{array}{l}\text { Managerial narratives, } \\
\text { corporate missions and } \\
\text { values statements. }\end{array}$ & $\begin{array}{l}\text { Assessment of the } \\
\text { organisational, cultural and } \\
\text { inter-functional influences } \\
\text { that enable and constrain } \\
\text { the practice of marketing } \\
\text { and power of marketers. }\end{array}$ & $\begin{array}{l}\text { Marketing management, } \\
\text { critical marketing, } \\
\text { organisational theory } \\
\text { literatures. }\end{array}$ \\
\hline
\end{tabular}




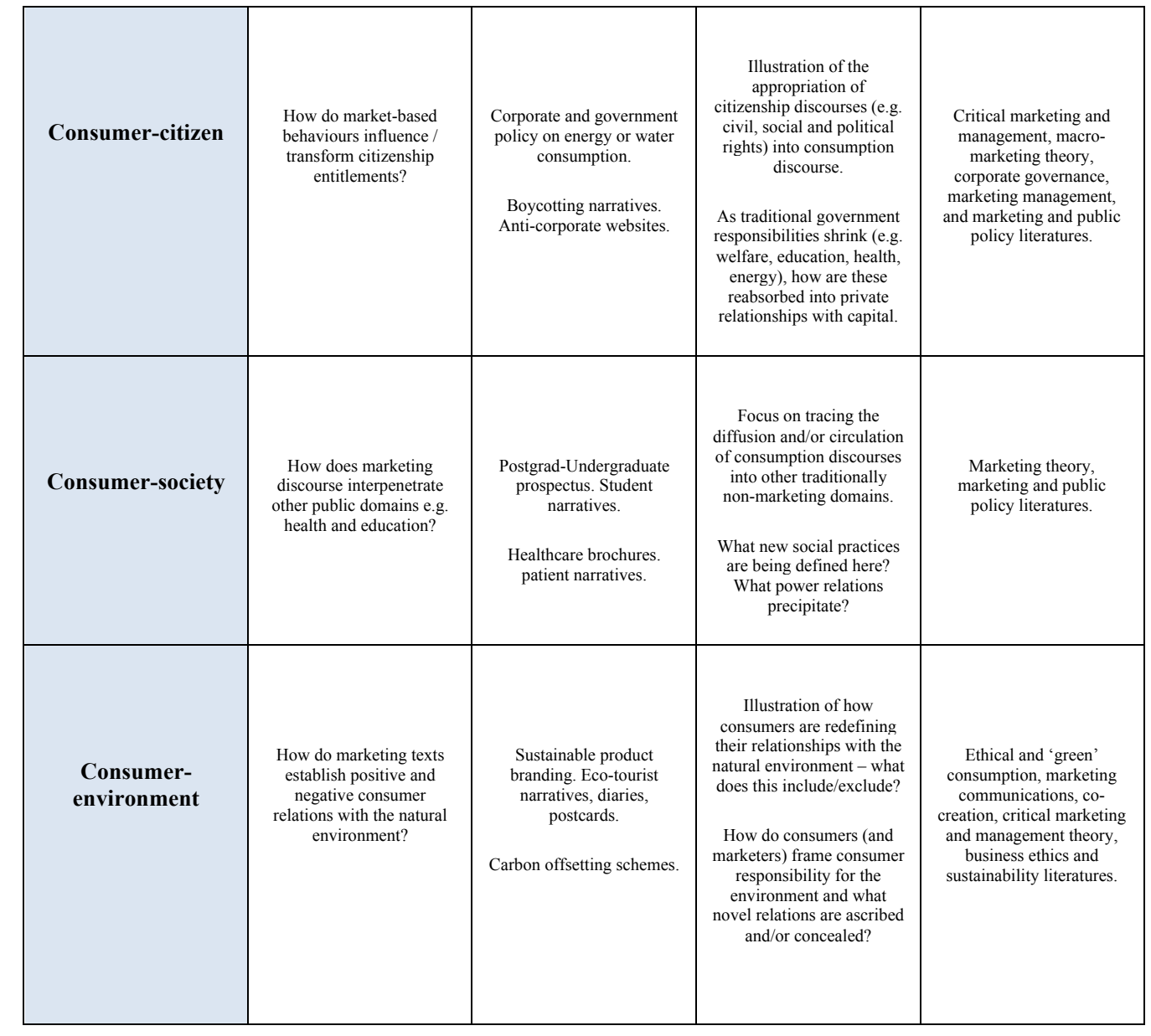

